\title{
The Effects of the COVID-19 Pandemic on the Paradigm Change in Agriculture
}

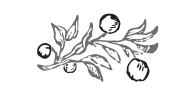

Summary

There have been successes and failures in combatting COVID-19 worldwide. News of the emergence of vaccines and the start of their widespread use give a ray of hope, but the battle is not over yet. Agriculture has a special role to play in this, as food should be maintained in all circumstances all over the world. There can be no question of a temporary shutdown in this sector. This study points out that the pandemic has caused labour shortages in seasonal work in both EU and US agriculture, which not only highlights, but also forces the acceleration of innovation-driven efficiency gains and generational change. Innovation in this case is aimed at reducing the need for human resources, and generational change is aimed at involving young women and men in agricultural production. The preservation and continuation of agricultural production is the basis for maintaining agricultural trade and the supply chain. The study sheds light on the short- and long-term effects and changes that the COVID-19 has caused in these areas. Success requires not only the development of the quantitative, but also the professional, qualitative preparation of the workforce, for which the authors recommend the wide application of talent management in agriculture and point out the most important elements of conscious preparation.

Journal of Economic Literature (JEL) codes: Q10, O1, I25, M12

Keywords: agriculture, economic development, training and economic development, personnel management

\footnotetext{
Dr Attila Szinay, State Secretary, Ministry of Agriculture (attila.szinay@am.gov.hu), Dr Attila Zöldréti, CSc of Economics, President, Department of Agriculture and Food Industry, Hungarian Economic Society (zoldreti.attila@uni-milton.hu), DR SzABolcs ZöldRÉti, Research Assistant, Farm Europe (szabolcs.zoldreti@farm-europe.eu).
} 
Attila Szinay, Attila Zöldréti, Szabolcs Zöldréti: The Effects of the COVID-19...

"Success is not final, failure is not fatal: it is the courage to continue that counts."

(Winston Churchill)

\section{THE EFFECTS OF COVID-19 ON AGRI-FOOD PRODUCTION AND TRADE}

In 2020, the situation of the agri-food business shows a complex picture, but we can already say at the outset that the sector has stood its ground and it has persevered in this situation as well. We can clearly say that the COVID-19 surprised the world, which was not prepared for the reception of a virus on such a global scale. Following the outbreak of the pandemic in the Far East, the first official reactions and recommendations were made only several months later even in the EU and the US, only after the pandemic had hit their territories.

This delay accompanied by divergent policies and responses also contributed to the rapid global spread of the virus. Combatting the pandemic soon became the key issue in 2020, both in terms of human health and the economy. The strategic importance of agri-food production and trade became an objective reality when the pandemic erupted worldwide. As healthy and adequate food should be ensured in all circumstances at present and in the future; stopping production and supply processes in agriculture has been out of the question. The combat against the pandemic exposed this sector to different problems than the sectors where actual shutdowns had to be made in production or in services (Lentner, 1998).

The first measures taken upon the arrival of the pandemic were focused on the protection of human health and then on stabilising the economy and maintaining the functioning of the Single Market.

On 16 March 2020, the Commission of the EU presented its guidelines to the Member States on health-related border management measures in the context of the COVID-19 emergency. The relevant communication states that the aim was to protect citizens' health, ensure the appropriate treatment for people who do have to travel, and make sure essential goods and services remain available. In the context of the guidelines, President von der Leyen said: "Our measures to contain the Coronavirus outbreak will be effective only if we coordinate on the European level. We have to take exceptional measures to protect the health of our citizens. But let's make sure goods and essential services continue to flow in our internal market. This is the only way to prevent shortages of medical equipment or food. It's not only an economic issue: our single market is a key instrument of European solidarity. I am in discussion with all Member States so that we confront this challenge together, as a Union" (European Commission, 2020a, p. 1).

The start of the "defence process" was, however, not trouble-free. Member States in the EU did not respond at the same time and in the same way. The applied restrictions and border closures, and households' panic purchases, caused disruption and supply difficulties in some products in the first days. Despite these minor distur- 
bances, the agri-food supplies have remained relatively stable and had been secured throughout the EU and the US, where similar processes took place earlier this year.

In addition to the human healthcare measures, great efforts have been made worldwide, including both the EU and the US, in agriculture to ensure food production and trade, and thus to maintain supplies. In September, the G20 Agricultural Ministers issued a statement underscoring the importance of maintaining agricultural trade flows during the COVID-19 pandemic and emphasising their commitment to remaining reliable suppliers of food and agricultural products to the world, and highlighting that reliable and resilient agricultural supply chains remain essential to guarantee the availability of safe, nutritious food around the world.

Examples and measures taken from the other side of the Atlantic included the USDA's farm programmes and assistance to agricultural producers, which involved billions of dollars in payments in the Coronavirus Food Assistance Program or other initiatives, such as the allowance of meal services during school closures to ensure that children receive nutritious meals while their schools are temporarily closed (USDA, 2020).

According to Census Bureau 2020 data, in the US, similarly to the EU, there is stabilisation in agricultural trade following the decline seen at the beginning of the year, as the October 2020 exports and imports reflect both the ongoing impact of the COVID-19 pandemic and the continued recovery from the sharp declines earlier that year.

Concerning the EU's response, direct support to farmers and rural areas, and exceptional market measures were taken for strengthening the food security and to guarantee an efficient food supply chain, with the aim to make use of the available funds under existing rural development programmes to provide support to farmers and SME's worsthit by the COVID-19 crisis and to address the liquidity and cash-flow problems stemming from the closures of shops, markets and restaurants (European Council, 2020).

The foregoing highlights that great efforts have been made in both the EU and the US to sustain agricultural production and supply and related trade. Nevertheless, the different response times and diverging measures with the lack of coordination related to the viral pandemic have indeed resulted in significant and hectic fluctuations in world trade overall. The WTO Global Trade Report, published in June 2020, shows a sharp fall of 27 per cent in trade contracts for Q2, which exceeded the 2008 global crisis. Already in this report, reference is made to the special situation of the agricultural sector, as in the breakdown by sectors, the agri-food trade showed only a seasonal (winter) decline associated with the usual seasons. In contrast, growth started as early as April, counter to the spectacular and cumulative decline in car sales, for example. In its October report, the Global Trade already shows the "bounce back" of world trade, which is illustrated in Figure 1.

This is explained by the summer recurrence of the virus, and the explosive commercial growth of anti-virus tools and equipment. The October 2020 report shows lower but stabilising trade turnovers than in previous years, while diverging sectoral responses persisted. As an example, Figure 2 clearly illustrates a repeated very significant difference between the previously mentioned automotive industry and the agri-food sector. The figure also plainly shows the stability of agri-food trade in 2020 . 
Figure 1: Global trade in goods stabilised at lower levels

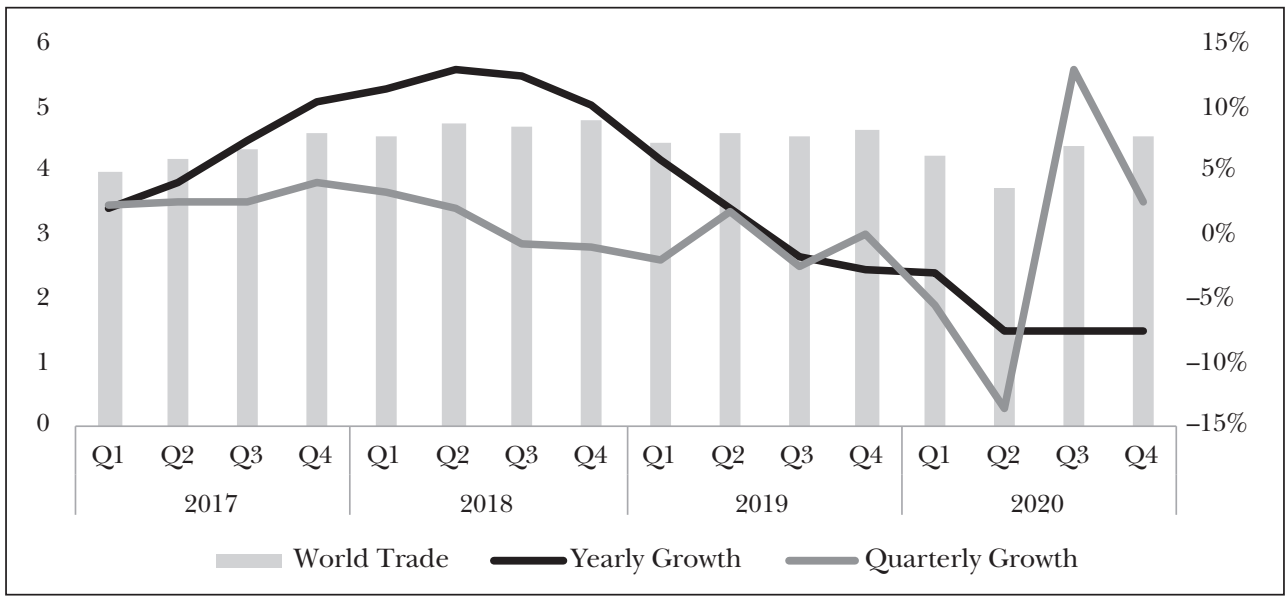

Source: Global Trade, 2020

Figure 2: COVID-19 has different effects by sectors in world trade

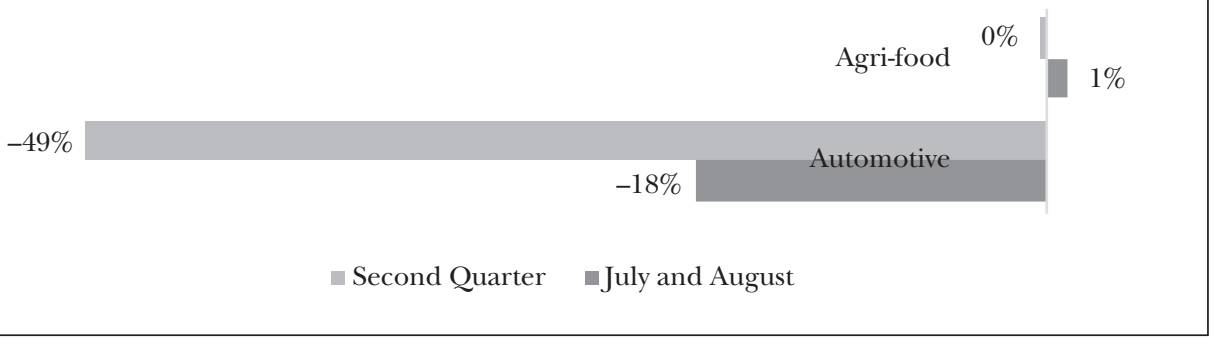

Source: Global Trade, 2020

The WTO's World Trade Statistical Review 2020, which looks into the latest developments in world trade, with a detailed analysis of the most recent trends for trade in goods and services, gives us further guidance regarding the resilience of the agri-food sector. According to this WTO report, agri-food exports show an annual growth rate of 7 per cent in trade in agricultural products over the past 20 years, but the pace has been declining since the 2008 crisis. In addition, since 2000, the largest increase in the world exports of food was recorded in 2008, following the 2007-2008 world food price crisis $(+22 \%)$. The largest decline was recorded in $2009(-10.5 \%$, WTO, 2020). The findings of the WTO report on the rapid development and then slowdown in agri-food trade in recent decades are in line with those of the FAO, which also establish that COVID-19 has reduced the growth rate of value chains and, at the same time, has shortened supply chains.

While according to FAO, global agri-food trade has more than doubled since 1995, with the rise of global agri-food value chains (GVC), the 2020 report shows that 
COVID-19 is slowing down the growth rate in value chains: the financial crisis of 2008 and the consequent economic slowdown stalled the evolution of agri-food GVCs, and the COVID-19 pandemic is expected to further disrupt their potential in global trade and growth $\mathrm{f}$ (FAO, 2020). FAO also lists the various trends and drivers behind the evolution of trade and markets, which include foremost technological progress, urbanisation, population and income growths; lower transport costs, trade policies and a decline in average import tariffs.

As a result of the measures taken, in contrast to fluctuations in world trade, agricultural production and trade showed balanced trends in the EU following seasonal fluctuations in 2020, based on The EU Commission's data for Q3 2020. The report points out that "despite the continuing COVID-19 crisis, EU agri-food trade remained strong during the first seven months of 2020" and thus agri-food trade in the EU has maintained growth in the period between January and July 2020.

Figure 3: EU27: Trade in agri-food products (EUR million)

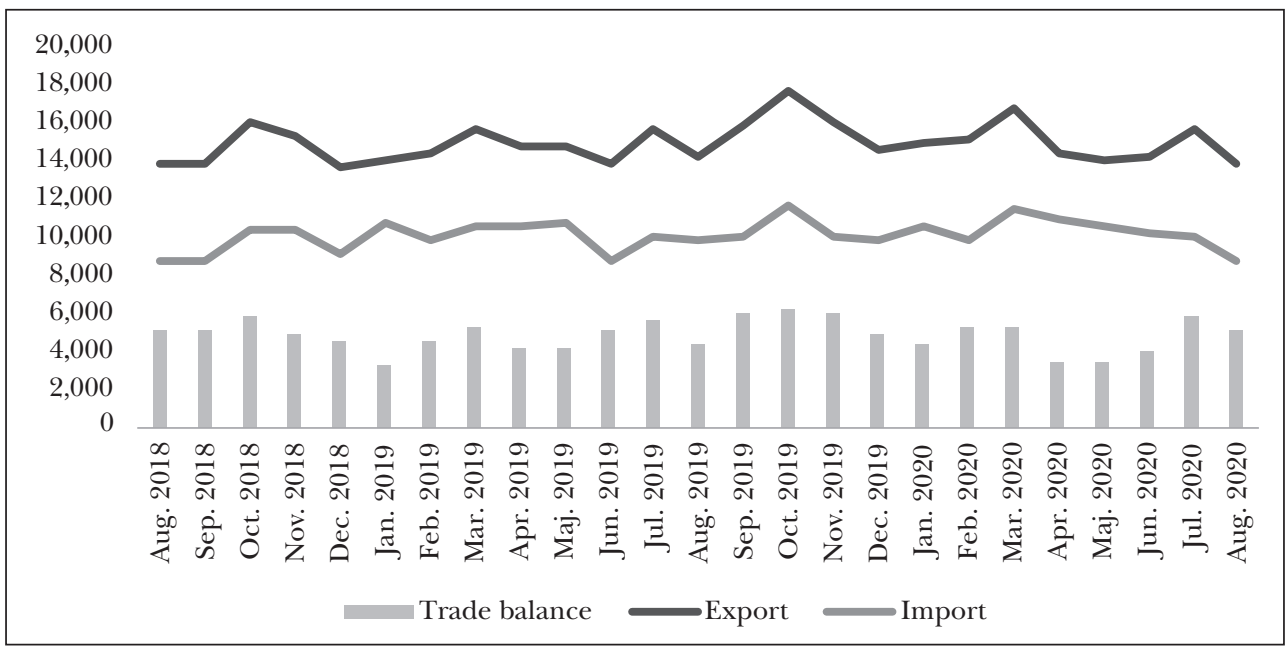

Source: European Commission, $2020 b$

The measures taken in the EU27 have ensured stability in agriculture. This was also manifest in Hungary, despite the fact that seasonal labour shortages were also experienced due to border locks and movement restrictions. Over the past 10 years, the Hungarian economy has successfully tackled public finance problems (Lentner, 2015), achieved significant results in economic growth, and competitiveness has also started to catch up (Matolcsy, 2019).

Similarly to other countries, COVID-19 posed healthcare and economic challenges in Hungary. Healthcare measures were followed by economy protection measures. Task forces were set up to comprehensively organise COVID-19-related healthcare and economic protection and restart. The Hungarian Economic Society's Department of Agriculture and Food also developed recommendations, and several of them 
were implemented during the year. These included strengthening short supply chains and the involvement of young local workers to better risk.

As a result of the measures, Hungarian agri-food trade also remained stable in 2020. According to the 2020 estimate issued by KSH (Central Statistical Office of Hungary) on 11 December 2020, the total output of agriculture increased by 4.1 per cent in 2020. Production volume decreased by 2.1 per cent and prices increased by 6.3 per cent. The volume of crop production decreased by 2.9 per cent, that of animal husbandry by 1.6 per cent and that of services by 3.0 per cent. The production of potatoes and animal products increased, while the production of other agricultural product groups decreased or remained unchanged (KSH, 2020a).

\section{NEW HUMAN RESOURGES NEED TO BE INVOLVED \\ IN THE AGRI-FOOD SECTOR}

COVID-19 has pointed out that cross-border and cross-regional supply chains and GVC's pose a greater risk to security of supply than shorter supply chains.

Labour shortages have revealed dependence on incoming labour from abroad, as it is the case in Great Britain, Spain or Germany, which have made special deals with some Eastern European countries to allow foreign workers enter their countries for harvest (Kühnel, 2020).

COVID-19 has enhanced the role of local production and consumption. Agri-food production and trade statistics show that even during the COVID-19 pandemic, the sector managed to perform its basic task, i.e. food supply. The EU maintained its global leadership in agri-food trade in 2020, ahead of the US. As a result of the restrictive measures taken to protect human life and the shutdown of most productive and service sectors, unemployment has increased. However, travel restrictions, quarantines and border closures have resulted in labour shortages in agri-food production, especially in terms of seasonal labour demand.

The most practical way to involve new human recourses is to make young people interested in agriculture and to provide additional resources to the sector through integration. Currently, the average age of farmers is high. In order to meet this human capacity requirement, technologies need to be developed rapidly to replace human labour, and this requires putting the results of innovation into practice.

Thanks to innovation, revolutionary changes are taking place in world agriculture. In the two decades since the turn of the millennium, greater progress has been made than in the previous hundred years. Hungarian agriculture should also adopt technical and technological innovations in order to achieve rapid performance growth. Meeting the need for human resources worldwide is one of the main directions in agricultural innovation.

The application of innovation results to farmers in both the EU and the US is supported by a number of professional thinktanks and organisations, such as the Farm Europe or the EIT Food. In addition to undertaking the professional representation of farmers, they also help farmers by training and advice, as has been comprehensively 
Civic Review · Vol. 16, Special Issue, 2020

discussed in the framework of the "renewed trade policy for a stronger Europe consultation" on the necessary areas for the development of a more efficient agricultural management and trade policy based on the experience of COVID-19. The world we live in is changing dramatically with significant changes to our society, how we look at opportunities and how we respond to challenges.

\section{FARMS MANAGERS ARE TYPICALLY MALE AND RELATIVELY OLD}

Agricultural production, which is the basis of food, is provided by the rural population, so in addition to urbanisation, efforts should be made to improve the retention capacity of the countryside in order to facilitate and support the retention and relocation of young people (Lentner et al., 2017). Hungary is also making serious efforts in this area (Lentner et al., 2018). The "Hungarian Village Project" and the Village Family Home Allowance (CSOK) are definite steps to increase the retention power of the countryside.

In addition to promoting housing, a rural employment environment encouraging for young people should also be developed as sources of absorption and retention. In agriculture, such an environment should be composed of two interrelated but well-distinguished main branches. One is related to the start-up and growth of young people as self-employed farmers, and the other is related to generational change. In this classic case, the management and ownership of the existing and operating agricultural units should be transferred to a person representing the younger generation in the family.

Figure 4 shows the situation of young farm managers and the aging rate in the EU. The ratios correspond to the Hungary's data. In Hungary, the ratio of managers under the age of 35 is 6 per cent, which is very similar to the EU average. The problem is that between 2000 and 2010 this ratio dropped to the EU average, as the ratio of young farmers under the age of 35 fell by 2.1 percentage points over this period. The EU constantly monitors age-related issues under the Common Agricultural Policy (CAP, European Commission, 2018a). Generational change is also promoted in the US, where the number of young farmers has increased by 2 per cent according to the most recent farm census (USDA, 2017).

Recognising the need to support young people, the EU provides EUR 40,000 in support to help young farmers set up farms. This support is available in Hungary in 2020 under the Young Farmers 2020 (VP6-6.1.1-16) call for tenders.

In addition to the establishment of a farm's economy, the support also aims to promote the transformation of farm structure, to improve the age structure of the agricultural workforce, to increase the population retention capacity of the countryside and to maintain agricultural activity in the long term.

Economic managers' aging is not country-specific, as the corresponding ratios practically coincide with the EU average. In Hungary, the ratio of farm managers over the age of 65 is 31 per cent, as pointed out in the Young Farmers 2020 (VP6-6.1.1-16) tender. 
Attila Szinay, Attila Zöldréti, Szabolcs Zöldréti: The Effects of the COVID-19...

Figure 4: Age structure of agricultural managers in the EU

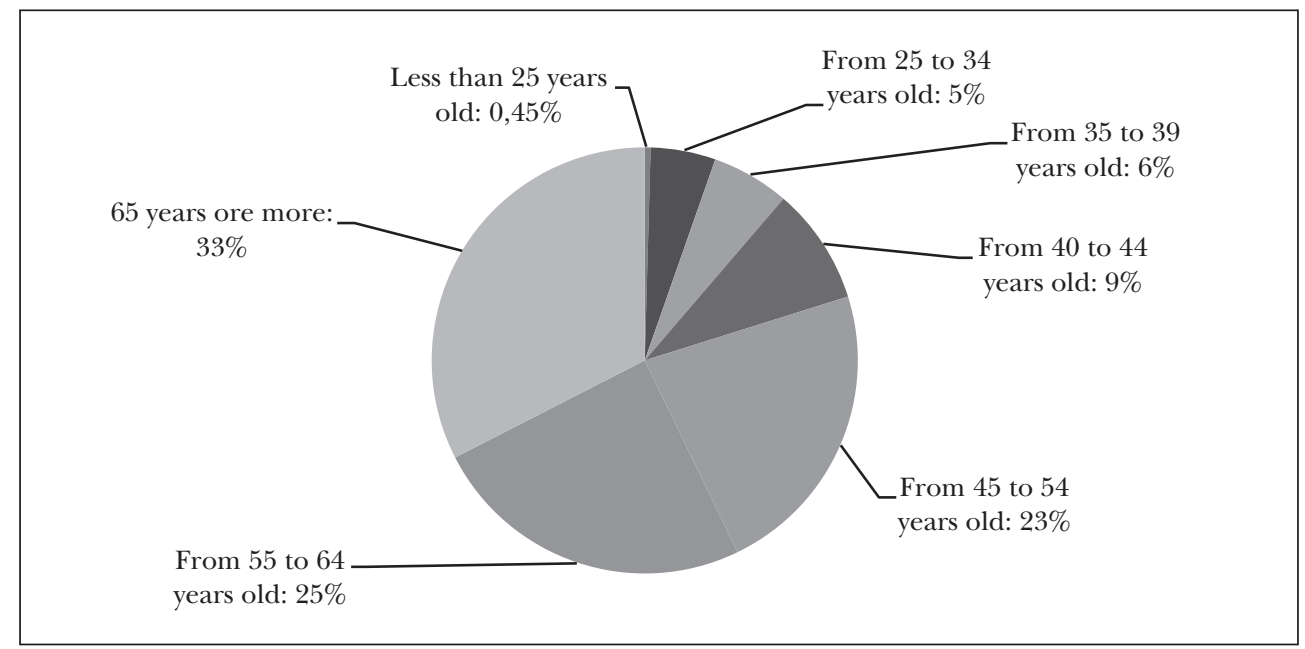

Source: European Commission, $2018 a$

Figure 5: Ages of farm managers, by gender, EU28 (\%)

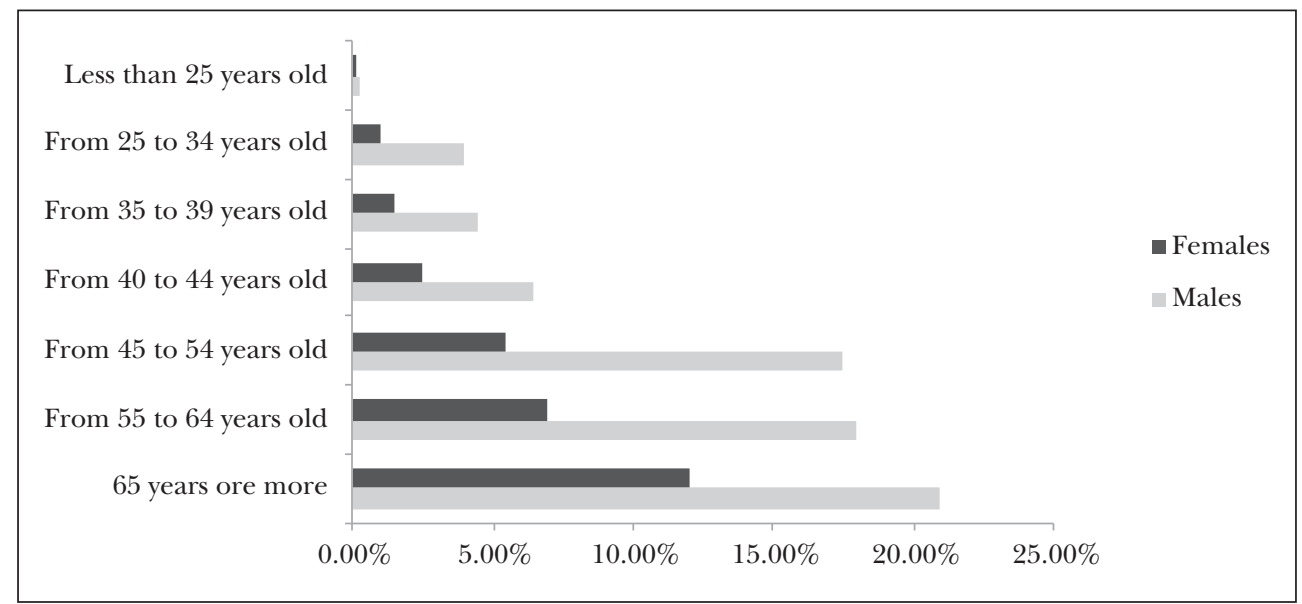

Source: European Commission, 2018 a

It should be emphasised, however, that in addition to aging at an EU level, there are countries where the situation is better. In Austria, Poland and Slovakia, the situation is better, while in the Mediterranean countries such as Cyprus, Portugal and Malta it is worse than average (European Commission, 2018a). At an EU level 28 per cent of the farms have a female farm manager. In Hungary, the ratio of female farm managers is 27 per cent, which is in line with the EU average. The pyramid of female leaders coincides with that of men at the EU level, which also raises the need for a generational change in their case. 
Civic Review · Vol. 16, Special Issue, 2020

\section{VERY FEW FARM MANAGERS IN THE EU HAVE FULL AGRICULTURAL TRAINING}

According to the European Commission, the ratio of fully trained farm managers is very low at an EU level. In the case of Hungary, unfortunately, this is even worse. While in Hungary 7.6 per cent of the farmers under the age of 35 have tertiary qualifications (full agricultural training), in the EU it is 21.7 per cent on average (European Commission, 2018b), which is primarily increased by the Czech Republic, Belgium and Ireland, while the lowest performing states include Romania, Spain and Greece. Hungary's backlog has also been recognised by domestic regulators, who are currently working to establish a firm vision for young people by renewing and making secondary and higher vocational education more attractive to increase the attractiveness of the sector. The goal is twofold. The aging generation should have the opportunity to retire. As the younger generation adapts to new technological solutions faster and, in this context, their willingness to invest is also higher than that of the older generation, a change in momentum and an increase in performance and competitiveness are expected (Lentner, 2007). The current situation is no longer sustainable, mainly due to the time required for a conscious generational change.

In Hungary, generational change is prevented by young people's disinterest in the agricultural sector. The following figure shows this trend over the years.

Figure 6: Distribution of students participating in higher education by fields of specialisation

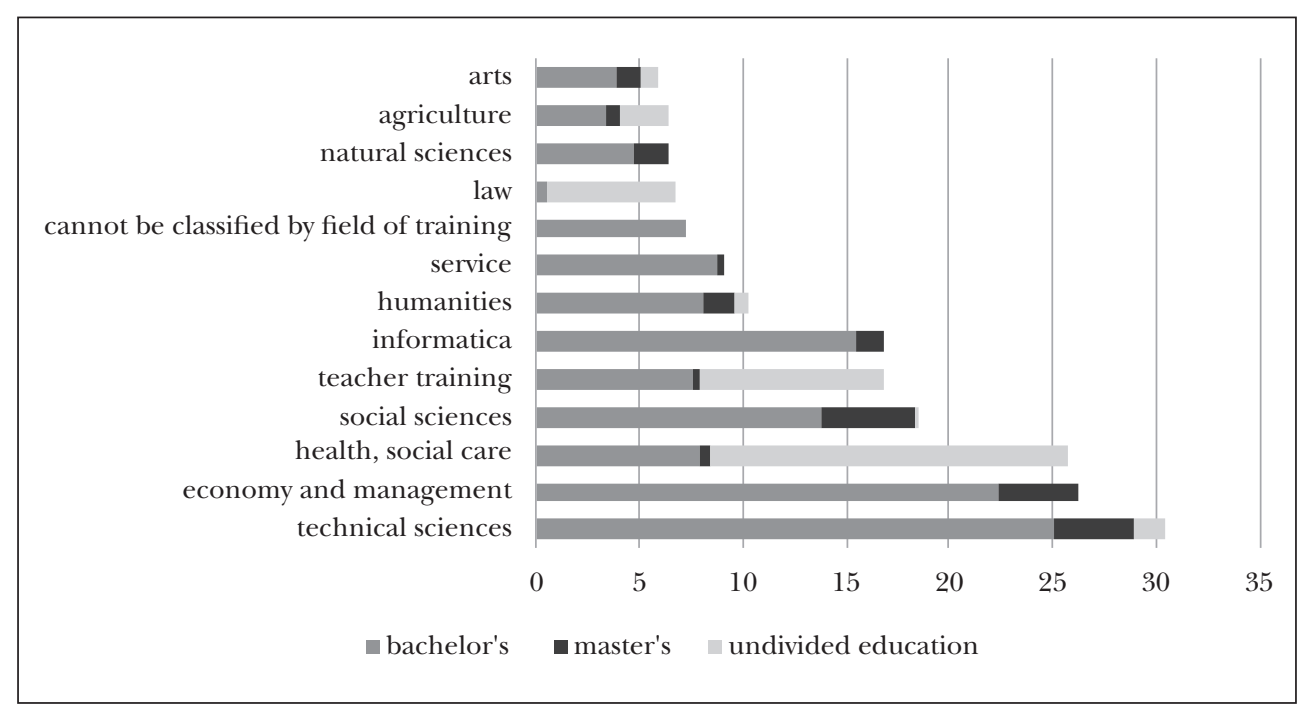

Source: KSH, $2020 b$

The combination of agricultural universities, implemented in 2020, will provide not only professional concentration, but also attractive training conditions for young people. Based on this, interest is expected to increase. 
Attila Szinay, Attila Zöldréti, Szabolcs Zöldréti: The Effects of the COVID-19...

THE ROLE OF PROFESSIONAL TALENT, COURAGE AND AWARENESS

IN THE GENERATIONAL CHANGE IN AGRICULTURE

A common feature of talents is that they are professionally motivated and take pleasure in challenging activities (Thom and Zöldréti, 2019). It is also widely accepted in the agricultural economy that during the outbreak of the Fourth Industrial Revolution, the future competitiveness and growth potential of businesses and individual countries are fundamentally determined by the capacity and quality of the human capital they can employ. Whoever is able to educate, develop and retain, or even attract, trained talent and the best workforce, has a chance to retain its market position or improve in the years to come. It is an unfortunate fact that this finding is now increasingly valid in a period of labour supply problems caused by the COVID-19 pandemic.

In the private sector, market competition has now led to a regular struggle to obtain resources with high human potential. Why would it be any different in agriculture, where there is also a huge competition for markets? From time to time, the question of "buying or nurturing" is raised by competitors in connection with the possession of talent. All of this is a little different for traditional family businesses. In their case, with regard to the future supply of skilful talent, the question is: Is there a talented, interested and motivated person in the family who can be involved in maintaining and improving processes by enforcing joint and mutual benefit maximisation? Let's consider the factors of the question asked.

In order to encourage young people, as pointed out by the BCG/WFPMA collaboration for Creating People Advantage 2014-2015 (BCG-WFPMA, 2015), in addition to new technological challenges, the work environment, community and development perspectives are key factors. According to their survey, for young employees, the recognition of professional work and aspects of work culture are more important than financial aspects when choosing a job.

Naturally, this also applies to the case of an agricultural family business. So it is not self-evident that the talented young person has an interest in the family business, even in spite of financial interest. Otherwise, the young person is driven by other goals like independence, detachment from family and local ties, and the family business profile may be a completely different objective incompatible with his or her ambitions.

In order to motivate young people, the opportunity to fulfil personal ambitions should also be provided. Today, precision agriculture provides a good background for this, because the challenges of using IT and robotics embody the challenges of the future, which are at the heart of most young people's interests, and provide a bridge to young people's interest in less attractive sectors of agriculture.

The pursuit of common and mutual benefit between generations is also based on motivation, which stems from a common interest in the success of generational change. However, this also requires courage on both sides, which always plays an important role in decisions. Winston Churchill's famous saying prevails in generational change and the sequel that goes with it that "Success is not final, failure is not fatal: the courage to continue is what matters". This courage to take over and continue is essential to successful generational change. 
Civic Review · Vol. 16, Special Issue, 2020

It takes courage on the part of the transferring older generation to part with the unit it has created and operated and to move into retirement, and it takes courage to rely on the younger generation. Nevertheless, on the other hand, it also takes courage on the part of the younger generation to take responsibility for operation, maintenance and development.

\section{OUR COMMON GOAL IS TO DEVELOP TALENT AND SUCCESSFULLY MANAGE IT}

Talent development and management is nothing more than a conscious investment in people. The cost side of this investment is given by "education" or "acquisition", while the revenue side is given by the excess revenue from the performance increase achieved by the "investment". Expenditure and revenue results can be tracked by factual data, including for farmers.

The steps of the talent management process and the expected time required for the various steps are summarised in Figure 7.

Based on all this, it can be seen that in the case of preparing for a conscious agricultural generational change, the expected time required for primary and secondary education or vocational training, or preparation for taking over management, can take up to 10-14 years. All this clearly highlights that this requires a carefully considered long-term family development plan and intention and its implementation, which requires a high degree of awareness throughout the process.

In raising awareness, the family pattern can be a good example for the young person. The family should work together to gain the interest of the talented young person, to introduce them to farming, to recognize and consciously develop the potentials hidden in the young person, and to turn the talent of the person concerned to the benefit of the business. It should be emphasised here that talent alone is not equal to performance; it only brings results with actual performance. Thus, in addition to developing individual ambition, reality should be ensured by evaluating incentives and performance. The complex system of talent management is discussed in detail in another study (Thom and Zöldréti, 2019).

Figure 7: Time required for conscious talent management

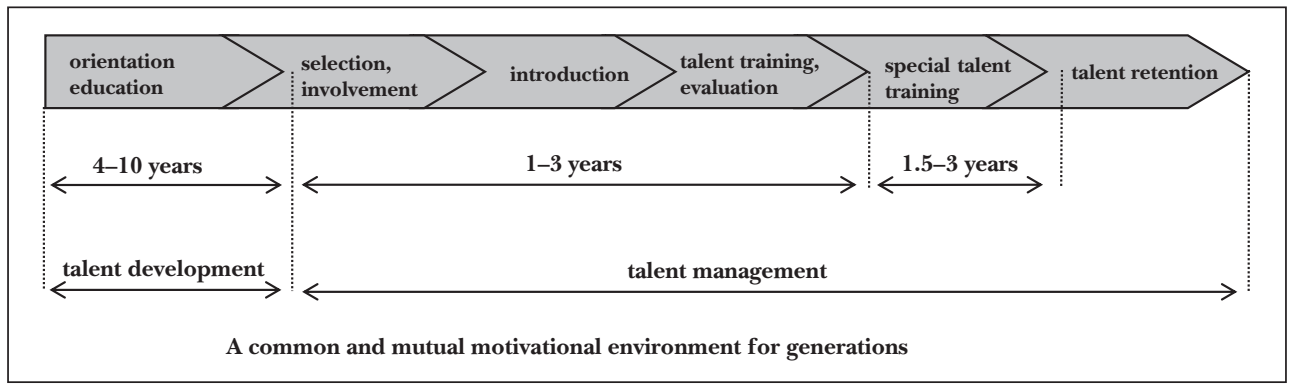

Source: Authors's own elaboration based on Thom and Zöldréti, 2019 


\section{Attila Szinay, Attila Zöldréti, Szabolcs Zöldréti: The Effects of the COVID-19...}

Different methodological considerations are available for selecting talent. The SWOT (strengths, weaknesses, opportunities, threats) analysis is most often used. This method is also recommended and very easy to apply for the self-assessment of the members in agricultural family businesses. In order to assess the role of talent management in Hungary, a questionnaire survey was conducted (Zöldréti, 2020) on generational change. It was found that 90 per cent of respondents agreed that it was of paramount importance for a generational change. The use of talent management in preparation is justified by increase in performance and competitiveness.

The survey also focused on the need for support related to talent management. Regarding the nature of the support, 50 per cent of the respondents preferred direct professional support (e.g. education, counselling) over financial support, which only 16 per cent indicated exclusively. The remaining 34 per cent considered the combination of direct professional and financial support as optimal. The survey also confirmed that conscious talent management appears in the practice of large international companies in Hungary. SMEs are aware of the importance of this topic, but for the time being the level of conscious application is very low in their case, so in their case this should be supported in order to have a successful generational change. Generational change and talent management should be seen as a project and tools learned in management should be used for success. These findings are summarised in our other study (Szinay and Zöldréti, 2020).

\section{SUMMARY AND PERSPECTIVES}

Focussed combat against COVID-19 needs to continue. To the best of our current knowledge, agri-food production and trade continues to provide for humanity on a global scale, fulfilling its strategic mission. Under no circumstances should this sector come to a standstill, as it would have consequences that should be prevented at all costs.

COVID-19 resulted in hectic movements in world trade in 2020, but this has resulted in only minor movements in the agri-food sector. The restrictions imposed also apply to the seasonal agricultural workforce, and thus forced the sector to rapidly apply the results of innovation to replace labour force and to attract new young labour. This compulsion also points to the need to speed up the preparation and management of young talent in Hungary as well. In the absence of seasonal workforce, the local, young generation needs to be involved in overcoming difficulties and won by innovation-retaining skills. Increasing the retention capacity of the countryside can also be improved through the attractiveness of the agricultural sector. This requires increasing the acceptance of agriculture by young people, in which innovation and the digital acquis may be an attractive challenge for them. 
Civic Review · Vol. 16, Special Issue, 2020

\section{REFERENGES}

BCG-WFPMA (2015): Creating People Adventage 2014-2015. The Boston Consulting Group, World Federation of Personnel Management Association, www.eapm.org/wp-content/uploads/2014/12/BCG_Creating_People_Advantage_2014-2015.pdf

BEA (2020): Coronavirus (COVID-19) Impact on International Trade in Goods and Services. www.bea.gov/ news $/ 2020 /$ test- 0 .

European Commission (2018a): Cap Context Indicators 2014-2020. 23. Age Structure of Farm Managers. European Commission, https://ec.europa.eu/info/sites/info/files/food-farming-fisheries/farming/documents/cap-indicators-doc-c23_2018_en.pdf

European Commission (2018b): Cap Context Indicators 2014-2020. 24. Agricultural Training of Farm Managers. European Commission, https://ec.europa.eu/info/sites/info/files/food-farming-fisheries/farming/documents/cap-indicators-doc-c24_2018_en.pdf

European Commission (2020a): Covid-19: Commission Presents Guidelines for Border Measures to Protect Health and Keep Goods and Essential Services Available. European Commission, https://ec.europa.eu/commission/presscorner/detail/en/ip_20_468

European Commission (2020b): EU Agri-food Trade Sustains Growth During January-July 2020. European Commission, https:/ / ec.europa.eu/info/news/eu-agri-food-trade-sustains-growth-during-january-july2020-2020-nov-13_en

European Commission (2020c): Young farmers. European Commission, https://ec.europa.eu/info/foodfarming-fisheries/key-policies/common-agricultural-policy/income-support/young-farmers_en

European Council (2020): Increased Support for EU Farmers Affected by the Covid-19 Crisis: Council Adopts Exceptional Measures. www.consilium.europa.eu/en/press/press-releases/2020/06/24/increased-support-foreu-farmers-affected-by-the-covid-19-crisis-council-adopts-exceptional-measures /.

FAO (2020): The State of Agricultural Commodity Markets. Food and Agriculture Organisation, www.fao.org/ publications/soco/en/.

Global Trade (2020): Global Trade: a Frail Recovery in the Second Half of 2020. https://unctad.org/system/ files/official-document/ditcinf2020d4_en.pdf

KSH (2020a): Agriculture. www.ksh.hu/agriculture.

KSH (2020b): Oktatási adatok, 2019/2020 [Data on education]. www.ksh.hu/docs/hun/xftp/idoszaki/oktat/oktatas1920/index.html.

Kühnel, A. (2020): Germany Drafts Romanian Farm Labor for Coronavirus Pandemic. DW, www.dw.com/ en/germany-drafts-romanian-farm-labor-for-coronavirus-pandemic/a-53066735.

Lentner, Cs. (1998): Dilemmas of Hungary's Agricultural Future Contrasted with its Historical Background and Developed Market Economy Models. In: Gidai, E. (ed.): On the Eve of the 21st Century. Challenges and Responses. Akadémiai Kiadó, Budapest, 175-185.

Lentner, Cs. (2007): A magyar nemzetgazdaság versenyképességének új típusú tényezôi [The new kind of competitiveness factors in the Hungarian economy]. In: Lentner, Cs. (ed.) (2007): Pénzügypolitikai stratégiák a XXI. század elején. Tiszteletkötet Prof. dr. Huszti Ernô egyetemi tanár 75. születésnapja alkalmából [Financial policy strategies in the early 21st centur. A volume in honour of Dr Ernô Huszti, university professor, on his 75th birthday]. Akadémiai Kiadó, Budapest, 271-297.

Lentner, Cs. (2015): The New Hungarian Public Finance System - in a Historical, Institutional and Scientific Context. Public Finance Quarterly, Vol. 60, No. 4, 447-461.

Lentner, Cs.; Novoszáth, P. and Sági, J. (2017): A magyar családpolitika és a születésszám alakulásának egyes kiemelt területei demográfiai, szociológiai és állampénzügyi vetületben, nemzetközi kitekintéssel [Certain key areas in Hungarian family policy and the number of births in a demographic, sociological and public finance perspective, with an international outlook]. Pro Publico Bono - Magyar Közigazgatás, Vol. 5, No. 4, 106-133.

Lentner, Cs. and Sági, J. (2018): Certain Aspect of Family Policy Incentives for Childbearing - A Hungarian Study with an International Outlook. Sustainability, Vol. 10, No. 11, https://doi.org/10.3390/ su10113976. 


\section{Attila Szinay, Attila Zöldréti, Szabolcs Zöldréti: The Effects of the COVID-19...}

Matolcsy, Gy. (2019): Successful Crisis Management in the Light of the Twelve Economic Turnarounds. Polgári Szemle/Civic Review, Vol. 15, Special Issue, 13-43, https://doi.org/10.24307/psz.2020.0202.

Szinay, A. and Zöldréti, A. (2020): Az agrár-generációváltás új dimenziói, különös tekintettel a koronavírus gazdasági hatásaira [New dimensions in generational renewal in agriculture, with special focus on the economic impacts of the coronavirus pandemic]. Polgári Szemle, Vol. 16, No. 1-3, 141-160, https://doi. org/10.24307/psz.2020.0709.

Thom, N. and Zöldréti, A. (2019): Ajánlások a gyakornok (trainee) programok sikeres lebonyolításához [Recommendations for the successful performance of trainee programmes]. Munkaügyi Szemle, Vol. 62, No. 6, 62-69.

USDA (2017): Young Producers - Selected Producer Characteristics, 2017. Census of Agriculture, www.nass.usda. gov/Publications/AgCensus/2017/Full_Report/Volume_1,_Chapter_1_US/st99_1_0068_0068.pdf.

USDA (2020): Joint Statement from Western Hemisphere Agriculture Leaders. www.fas.usda.gov/newsroom/jointstatement-western-hemisphere-agriculture-leaders-0.

WTO (2020): World Trade Statistical Review, 2020. World Trade Organisation, www.wto.org/english/res_e/ statis_e/wts2020_e/wts20_toc_e.htm.

Zöldréti, A. (2020): Tehetségmenedzsmenttel versenyképességünk szolgálatában [With talent management in the service of our competitiveness]. Opus et Educatio, Vol. 7, No. 1, 55-70. 